\title{
THE PROTEIN DIGESTIBILITY OF THE BROILER CHICKENS FED JAMU FORMULA, a LOCAL HERBAL SOLUTION
}

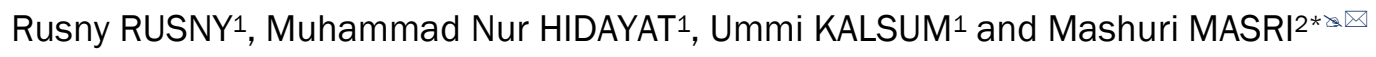 \\ ${ }^{1}$ Department of Animal Husbandy, Faculty of Science and Technology, State Islamic University Alauddin Makassar, South Sulawesi, Indonesia \\ ${ }^{2}$ Department of Biology, Faculty of Science and Technology, State Islamic University Alauddin Makassar, South Sulawesi, Indonesia \\ Email: mashuri.masri@uin-alauddin.ac.id; (D) ORCiD: 0000-0003-1148-7208 \\ Supporting Information
}

\begin{abstract}
Jamu (local herbal drinking) have been known for a long time by inhabitants in Indonesia as conventional home grown pharmaceutical and to progress digestion system within the body. Jamu, not as it were for people but also for creatures. Local farmers have moreover utilized jamu for chicken for a long time, and it's utilize is expanding. This Research points to decide the impact of jamu to extend protein in vivo digestibility in broilers and for knowing the ideal level of jamu for optimum protein digestibility in broilers. The strategy utilized in this investigate is Completely Randomized Design (CRD) with 4 treatment and 5 replications, each redundancy comprises of 1 broiler chickens, so there are 20 chickens. The treatment comprises of PO (control), T1 (jamu $1.5 \mathrm{~mL} / 500 \mathrm{~mL}$ ), T2 (jamu $2.5 \mathrm{~mL} / 500 \mathrm{~mL}$ ) and T3 (jamu $3.5 \mathrm{~mL} / 500$ $\mathrm{mL}$ ). The parameters watched were digestibility protein in broilers. Based on the examination of fluctuation, it appears The treatment had no critical impact on chicken protein broilers' digestibility given jamu. However, seeing each treatment's average value, T1, T2 and T3 tend to increase to $99.62 \%, 99.68 \%$ and $99.71 \%$, respectively. In conclusion, supplemented with jamu formula does not significantly affect broiler chicken protein's digestibility, but the digestibility increases with increasing formula, up to the formula $3.5 \mathrm{~mL} / 500$ $\mathrm{mL}$ (T3) as the ideal level.
\end{abstract}

Keywords: Broiler, Digestibility, Herbal treatment, Jamu, Protein.

\section{INTRODUCTION}

The demand for chicken meat increases along with increasing incomes and awareness of the importance of animal protein (Wilkie, 2005). Developing broiler production, and provide commercial feeds has fulfilled legal needs for farmers (Variani et al., 2017). Despite the price relatively expensive because some of the ingredients are still imported, some commercial feed ingredients are widely available and easy to obtain. Besides, it contains additional feed ingredients (feed additives) needed by livestock (Alqaisi et al., 2017).

Protein is a necessity nutrient for humans and livestock to be affect the growth period, age, physiology, production, and body condition. Protein digestibility is the ability of the protein to be hydrolyzed into amino acids by digestive enzymes (Hou et al., 2017). If protein digestibility is high, the protein can be well hydrolyzed into amino acids, so the number of amino acids that can be absorbed and used by the body sufficiently (Ketnawa and Ogawa, 2019). If the protein digestibility is a combined process to be hydrolyzed into amino acids then the amount Amino acids that can be absorbed and used by the body are in low rate due in part large will be disposed of by the body with feces (Deb-Choudhury et al., 2018). Its well-known, protein is very important in tissue repair energy metabolism and for obtaining vital substances in body functions such as enzymes (Shah et al., 2020).

Herbal formulation (Jamu) have been known for a long time by residents in Indonesia as traditional medicine and to improve metabolism in the body (Elfahmi et al., 2014). Jamu has been used for special targets not only for humans (Mosihuzzaman, 2012; Zhu, 2020) but also for animals (Alagawany et al., 2019; Zhu, 2020). Local farmers have also used jamu for chicken for a long time, and its use is increasing (Gaucher et al., 2015; Galli et al., 2020). Based on information in the field, some breeders who use jamu can increase their livestock productivity, for example Galli's research fed jamu in breeders which increase quality of meat in fatty acid profile (Galli et al., 2020).

Agustina et al. (2017) showed that jamu in liquid or powder form can inhibit Gram-positive and Gram-negative bacteria, because the ingredients contain bioactive substances. It was necessary to reduce the types of materials suspected of having the same bioactive substances. The use of jamu in liquid form as much as $2.5 \mathrm{~mL} / \mathrm{L}$ of drinking water, is the best result of performance and histopathological abnormalities of internal organs. The use of $0.15 \%$ herbal concoction powder in feed effectively improves performance, reduces the number of deaths, abdominal fat, blood cholesterol, and gives the highest OD (Optic Density) value, which indicates that herbal concoction powder can prevent viruses (using a lubricant kit to test IFNy (Interferon-gamma). Based on this description, it is necessary to conduct a 
research on the use of herbal medicine in drinking water to determine the effect protein digestibility in broilers. Aim of present study was to determine the effect of jamu to expand protein in vivo digestibility in broilers and for knowing the perfect level of jamu for ideal protein digestibility in broilers

\section{MATERIALS AND METHODS}

The materials used in this study were $\mathbf{4 0}$ broilers, husk, and herbal solution with $\mathbf{2 5 0} \mathrm{g}$ of a mixture of ingredients, namely garlic (Allium sativum L.), leaves betel (Piper betle L.), cinnamon (Cinnamomum verum L.), EM-4 (Effective Microorganisms-4) and molasses. The feed used comes from a commercial feed, namely B11A with the composition of corn, rice bran, soybean meal, fish meal, meat bone meal, corn gluten meal, pollard, stone flour, crude palm oil, sodium bicarbonate premix, vitamins and trace minerals. While the material used to calculate digestibility protein, namely sample (feces), selenium \pm 1 gram, $25 \mathrm{~mL}$ concentrated $\mathrm{H}_{2} \mathrm{SO}_{4}$, distilled water $100 \mathrm{~mL}, 10 \mathrm{~mL} 2 \% \mathrm{H}_{3} \mathrm{BO}_{3}, 4 \mathrm{drops}$ indicator solution and $10 \mathrm{~mL} 30 \% \mathrm{NaOH}$.

\section{Research design}

This study used a completely randomized design (CRD) consisting of 4 treatments and 5 replications, each replication consisted of 2 broilers so that there are 40 experimental units with treatment (T), namely: T0: control; T1: Jamu $1.5 \mathrm{~mL} / 500 \mathrm{~mL} /$ drinking water; T2: Jamu $2.5 \mathrm{~mL} / 500 \mathrm{~mL} /$ drinking water; T3: Jamu $3.5 \mathrm{~mL} / 500 \mathrm{~mL} /$ drinking water.

\section{Broiler preparation and maintenance}

The cage must be prepared before day old chick (DOC) entered, cage preparation is done carefully and carried out to install curtains and cleaning and sterilization around the cage with how to spray detergent and the tools to be used and wait until dry. After that, it is covered with husks with a thickness of seven $\mathrm{cm}$ feed, and the area of the cage unit used is $60 \times 100 \mathrm{~cm}$. Preparations are maintained from DOC until the age of 30 days with a cage covered with husks. The treatment is given to chickens since the chicken entered the cage unit experiment until harvest. The number of treatment chickens was $\mathbf{4 0}$ chickens selected randomly and put into the cages of each experimental unit $\mathbf{2}$ tails. Each experimental unit enclosure is equipped with a 25 watt incandescent lamp as many as 20 pieces.

\section{Production of Jamu}

Materials used to manufacture herbal such as garlic, betel leaf, cinnamon first cleaned, then weighing 250 g each, then crushed use a blender for garlic and betel leaves, except for cinnamon ground using a mortar until smooth. Next third, the ingredients are mixed in one container. Addition of molasses and EM-4 (effective microorganisms-4) was also carried out each as much $1 \mathrm{~L}$ then add $10 \mathrm{~L}$ of water. Stir until all ingredients to be homogeneous (Jamili et al., 2014).

\section{Table 1 - Ingredients of Jamu used in present study.}

\begin{tabular}{lc} 
Ingredients & Composition \\
\hline Garlic & $250 \mathrm{~g}$ \\
Betel leaf & $250 \mathrm{~g}$ \\
Cinnamon & $250 \mathrm{~g}$ \\
EM-4 & $1 \mathrm{~L}$ \\
Molasses & $1 \mathrm{~L}$ \\
Well water & $10 \mathrm{~L}$ \\
\hline Source: Primer Data. & \\
\hline
\end{tabular}

\begin{tabular}{lc}
$\begin{array}{l}\text { Table } 2 \text { - Energy content of B11A feed used in present } \\
\text { study. }\end{array}$ \\
Content & Composition (\%) \\
\hline Water & 13.0 \\
Protein & $22.0-23.5$ \\
Fat & 5.0 \\
Fiber & 5.0 \\
Ash & 7.0 \\
Calcium & 0.9 \\
Phosphorus & 0.6 \\
\hline Source: PT. New Hope Indonesia, 2019 \\
\hline
\end{tabular}

\section{Feed and drinking water}

Feeding is done a few hours after drinking DOC (3-4 hours after the DOC is drinking). The provision of drinking water is carried out ad libitum (continuously), and in giving it must be clean and fresh, and the drinking water has been mixed with the herbal herbs that are given each day until the age of $\mathbf{3 0}$ days, and the giving is done according to treatment that has been determined in this study. The nutritional content of commercial feed B11A produced by PT. New Hope Indonesia is used in this study is presented in Table 2.

\section{Protein digestibility calculation process}

After going through the maintenance process, at the end of the study, fecal samples were taken from each treatment in the form of fresh ones that had been weighed previously to determine their fresh weight for further observation in the laboratory by the method of calculating protein digestibility, namely by weighing carefully weighing \pm 0 , $5 \mathrm{~g}$ of the sample, then put it in the Kjeldahl flask. A mixture of selenium $( \pm 1 \mathrm{~g})$ and $25 \mathrm{~mL}$ of concentrated $\mathrm{H}_{2} \mathrm{SO}_{4} \mathrm{Was}$ added. The Khjedhal flask and its contents were shaken until all samples were wetted with $\mathrm{H}_{2} \mathrm{SO}_{4}$ then digested in a fume 
hood until it was clear. Let it cool, then pour into a $100 \mathrm{~mL}$ volumetric flask and rinse with distilled water. Let it cool again, squeeze it to the mark with distilled water and then shook it until it was homogeneous. After that, a pan consisting of 10 $\mathrm{mL} \mathrm{H}_{3} \mathrm{BO}_{3} 2 \%+4$ drops of mixed indicator solution prepared into Erlenmeyer, then Pipette $5 \mathrm{~mL}$ of sample solution into a distillation flask, add $10 \mathrm{~mL}$ of $30 \% \mathrm{NaOH}$ and $100 \mathrm{~mL}$ of distilled water. Then it was distilled until the reservoir volume became $\pm 50 \mathrm{~mL}$. Rinsed the distiller's end with distilled water, then the container and its contents were titrated with a $0.0171 \mathrm{~N} \mathrm{H}_{2} \mathrm{SO}_{4}$ solution (Adedokun et al., 2008).

$$
\% \text { CrudeProtein }=\frac{V x N x 14 x 6.25 x P}{\text { sampleweight }(\text { gr })} \times 100 \%
$$

Description: V: volume of sample titration; $\mathrm{N}$ : normality of $\mathrm{H}_{2} \mathrm{SO}_{4}$ solution; P: dilution factor.

\section{Protein digestibility test by taking 1 sample from each test}

Observation of protein digestibility by knowing the data on feed consumption that has been added with herbal herbs to drinking water and weighing the feces in the ileum. The collection method of ileal digesta is by fasting for 14 hours. It is given commercial feed as much as $100 \mathrm{~g} /$ head and drinking water for 10 hours before slaughtering after being fast. Then the chicken is slaughtered. Digesta was taken from the small intestine part of the ileum, after $1 \mathrm{~cm}$ from Meckel's diverticulum to a limit of $1 \mathrm{~cm}$ before the ileum-cecal junction. After that, the digesta is removed, and then the initial weight is weighed in fresh form from each treatment. After that, the digesta was collected and then analyzed in vivo (Adedokun et al., 2008). According to Li et al. (2017), regarding the digestibility calculation method protein, namely the following formula:

$$
\% \text { ProteinDigestibility }=\frac{(\Sigma A x \% B)-(\Sigma C x \% D)}{(\Sigma A x \% B)} \times 100 \%
$$

Description: A: consumption of ration (g); B: food substances in the ration (protein, \%); C: number of feces (g); D: food substance in feces (protein; \%).

\section{Statistical analysis}

The data obtained will be analyzed through variance using a completely randomized design (CRD) with 4 treatments and 5 replications. If the treatment has a significant effect, then the Duncan multiple area test is continued to see the differences in each treatment sample. According to Ervina et al. (2019) the mathematical model of the CRD is as follows:

$$
Y i j=\mu+\alpha i+€ i j
$$

Description: Yij: The observed value of the $i^{\text {th }}$ treatment of jamu; $\mu$ : Real average value; $\alpha \mathrm{i}$ : effect of treatment at level I; $€$ ij: error; i: T0, T1, T2, T3 (treatment); j: 1, 2, 3 (repeat).

\section{Ethical approval}

The in vivo study was supervised by The Animal Ethics Committee of the Universitas Islam Negeri Alauddin and conducted in accordance with the basic animal husbandry and health protocols referred to in Legislation of the Republic of Indonesia No. 18, 2009.

\section{RESULTS AND DISCUSSION}

The results of the 23 days feeding jamu-treatment against protein digestibility in the cobb-500 broiler chicken presented in Table 3. The results of this analysis of variance indicated that the treatment has not significant effect $(P>0.05)$ on protein digestibility. The treatments were T0 (99.56\%), T1 (99.62\%), T2 (99.68\%) and T3 (99.71\%).

Protein digestibility is the amount of protein that is absorbed from food into particles absorbed by the digestive tract (Jonker and Yu, 2017; Cholis et al., 2018). In Table 3, the average value of T3 (99.71\%), which is given herbal herbs in chicken drinking water as much as $3.5 \mathrm{~mL}$, showed the value of protein digestibility as the highest among other treatments. In comparison, the lowest average protein digestibility value was PO (99.56\%) of all treatments. The treatment statistically has no significant effect on protein digestibility, but seen from the trend of research data, the feed of jamu with a dose of $3.5 \mathrm{~mL}$ can increase protein digestibility, this treatment has the highest value of all treatments with a value of $99.71 \%$. Alagawany et al. (2019) stated that cattle that consume high protein could affect their body cells'

\begin{tabular}{|c|c|c|c|c|c|}
\hline \multirow{2}{*}{ Variable } & \multicolumn{4}{|c|}{ Treatment } & \multirow{2}{*}{ P-value } \\
\hline & TO & T1 & T2 & T3 & \\
\hline Protein digestibility & $99.56 \pm 0.95$ & $99.62 \pm 0.15$ & $99.68 \pm 0.13$ & $99.71 \pm 0,07$ & 0.24 \\
\hline
\end{tabular}
metabolism to run correctly.

\section{Table 3 - Average digestibility and standard deviation of protein in broiler chickens fed jamu for 23 days.}


In the present study, the treatment given was in the form of jamu from several ingredients such as garlic, betel leaf, and cinnamon which had almost the same content as alicin, essential oils, flavonoids, tannins (Castillo-López et al., 2017; Alagbe et al., 2020), it's were able to increase protein digestibility in broilers and could be antibacterial (Alagawany et al., 2019; Alagbe et al., 2020). The working system of feeding jamu in livestock, which can improve metabolism, the digestive system and reduce pathogenic bacteria that can affect feed consumption absorption (Alagawany et al., 2019). Reduced pathogenic bacteria in the digestive system of livestock so that the protein also produced increases (Galli et al., 2020).

All ingredients' content works following their respective mechanisms that interfere with and even damage pathogenic bacteria so that their growth is blocked or dies (Alagawany et al., 2019; Galli et al., 2020). According to Castillo-López et al. (2017), alicin is one of the most active biological components in garlic (Castillo-López et al., 2017). Previously, Cardoso-Ugarte et al. (2016) argued that cinnamon's content has many compounds, namely essential oils (Cardoso-Ugarte et al., 2016). According to Jamili et al. (2014) when the betel leaf, garlic, and betel leaf are all mixed, it will have a robust inhibitory compound against Staphylococcus aureus and Salmonella thypi bacteria, namely tannins, essential oils, alisin, flavonoids, etc. which have their way to inhibit bacteria.

The contents of the materials used which have antibacterial properties work according to their respective mechanisms, for example, flavonoids, tannin alkaloids, and essential oil, which work to form more complex compounds then disrupt and even damage the test bacterial cell membranes so that the bacterial life activity is inhibited or dies (Alagbe, et al., 2020; Galli et al., 2020). Previously, Cheng et al. (2014) and Rabinowitch (2002) stated that allicin could inhibit the growth of negative and positive gram bacteria, and prevent abnormalities in the small intestine to better the intestine's protein absorption process (Cheng et al., 2014; Rabinowitch, 2002). The effect of this study was not significant $(P>0.05)$ because it could be caused by several factors such as provision of feed, bulkhead conditions, environmental conditions, provision of drinking water added with jamu in each treatment. According to Dersjant et al. (2015) and Olijhoek et al. (2018), the high and low digestibility of feed ingredients is influenced by several factors, including types of livestock, feed, types of feed ingredients in rations, crude protein content, and the way of providing rations, however this also shows that one of the factors that makes it insignificant is the amount of broiler consumption influenced by the form of feed and the protein content of the feed (Dersjant-Li et al., 2015; Olijhoek et al., 2018).

In present research, the form of feed used is commercial feed produced in pelleted form. According to Milanovic (2018), good feed for broilers such as pellets and crumble is because poultry has high palatability to add to its digestibility, poultry feed dramatically determines the level of protein digestibility so that the amount of feed and protein content that enters the digestive tract (Milanovic, 2018). The protein content in the feed used in each treatment was an average of $\mathbf{2 2 . 7 5 \%}$ from the starter-finisher period. Kaewtapee et al. (2017) and Olijhoek et al. (2018) stated that rations with low protein content generally have low digestibility and vice versa. The level of protein digestibility depends on the protein content of the feed ingredients, the amount of protein that enters the digestive tract, and the influence of the use of doses of antibiotics and probiotics given (Liao and Nyachoti, 2017; Clavijo and Flórez, 2018; Galli et al., 2020; Zaghari et al., 2020). The addition of doses from each treatment also dramatically determines the effect on the digestibility of the protein itself, the doses used in this study started from T1, T2, and T3 treatments, respectively, namely $1.5 \mathrm{~mL} / 500$ $\mathrm{mL} /$ drinking water, $2.5 \mathrm{~mL} / 500 \mathrm{~mL} /$ drinking water and $3.5 \mathrm{~mL} / 500 \mathrm{~mL} /$ drinking water, following the research of Kusbiyantari et al. (2017) which uses a betel leaf solution with a dose of $5 \%$ per liter of drinking water to increase protein digestibility.

\section{CONCLUSION}

The feeding of jamu had no significant effect on digestion of protein in broilers. T1, T2 and T3 tend to increase; $99.62 \%$, $99.68 \%$ and $99.71 \%$, respectively. In summary, supplementation with jamu does not essentially influence broiler chicken protein's digestibility, but the digestibility increments with expanding equation, up to $3.5 \mathrm{~mL} / 500 \mathrm{~mL}$ (T3) as the ideal level. Further studies with other local herbs and herbal solutions are suggested.

\section{DECLARATIONS}

Corresponding Author

E-mail: mashuri.masri@uin-alauddin.ac.id; ORCID: 0000-0003-1148-7208

\section{Authors' Contribution}

All authors contributed in research and writing, equally.

Conflict of interests

The authors declare that they have no competing interests.

\section{REFERENCES}

Adedokun, SA, Adeola, O, Parsons, CM, Lilburn, MS, and Applegate, TJ (2008). Standardized ileal amino acid digestibility of plant feedstuffs in broiler chickens and turkey poults using a nitrogen-free or casein diet. Poultry Science, 87 (12): 2535-2548. Doi: https://doi.org/10.3382/ps.2007-00387 I Article link

Agustina L, Syahrir S, Purwanti S, Jillbert J, Asriani A, and Jamilah (2017). Herbal ingredients in laying hens. Abdimas Journal, 21(1): 4753. Article link

Alagawany M, Elnesr SS, Farag MR, Abd El-Hack ME, Khafaga AF, Taha AE, Tiwari R, Yatoo MI, Bhatt P, Marappan G, and Dhama K (2019). Use of Licorice (Glycyrrhiza glabra) Herb as a Feed Additive in Poultry: Current Knowledge and Prospects. Animals, 9(8): 536. Doi: 
https://doi.org/10.3390/ani9080536 I Article Link

Alagbe JO, Shittu MD, and Eunice AO (2020). Prospect of leaf extracts on the performance and blood profile of monogastric - a review. International Journal on Integrated Education, 3(7): 122-127. Doi: https://doi.org/10.31149/ijie.v3i7.509 | Article link

Alqaisi O, Ndambi OA, and Williams RB (2017). Time series livestock diet optimization: cost-effective broiler feed substitution using the commodity price spread approach. Agricultural and Food Economics, 5(1): 1-9. Doi: https://doi.org/10.1186/s40100-017-0094-9 I Article Link

Cardoso-Ugarte GA, López-Malo A, and Sosa-Morales ME (2016). Cinnamon (Cinnamomum zeylanicum) essential oils. In Essential Oils in Food Preservation, Flavor and Safety (Issue 2000). Elsevier Inc, Netherland. Doi: https://doi.org/10.1016/B978-0-12-4166417.00038-9 | Article Link

Castillo-López RI, Gutiérrez-Grijalva EP, Leyva-Lópe N, López-Martínez LX, and Heredia JB (2017). Natural alternatives to growth-promoting antibiotics (GPA) in animal production. Journal of Animal and Plant Sciences, 27(2): 349-359. http://www.thejaps.org.pk/docs/v-272/01.pdf I Article Link

Cheng G, Hao H, Xie S, Wang X, Dai M, Huang L, and Yuan Z (2014). Antibiotic alternatives: The substitution of antibiotics in animal husbandry?. Frontiers in Microbiology, 5(MAY): 1-15. Doi: https://doi.org/10.3389/fmicb.2014.00217 I Article Link

Cholis MA, Suthama N, and Sukamto B (2018). Feeding microparticle protein diet combined with Lactobacillus sp. On existence of intestinal bacteria and growth of broiler chickens. Journal of the Indonesian Tropical Animal Agriculture, 43(3): 265-271. Doi: https://doi.org/10.14710/jitaa.43.3.265-271 I Article Link

Clavijo V, and Flórez MJV (2018). The gastrointestinal microbiome and its association with the control of pathogens in broiler chicken production: A review. Poultry Science, 97(3): 1006-1021. Doi: https://doi.org/10.3382/ps/pex359 I Article Link

Deb-Choudhury S, Bermingham EN, Young W, Barnett MPG, Knowles So, Harland D, Clerens S, and Dyer JM (2018). The effects of a wool hydrolysate on short-chain fatty acid production and fecal microbial composition in the domestic cat (Felis catus). Food and Function, 9(8): 4107-4121. Doi: https://doi.org/10.1039/c7fo02004j I Article Link

Dersjant-Li Y, Awati A, Schulze H, and Partridge G (2015). Phytase in non-ruminant animal nutrition: A critical review on phytase activities in the gastrointestinal tract and influencing factors. Journal of the Science of Food and Agriculture, 95(5): 878-896. Doi: https://doi.org/10.1002/jsfa.6998 | Article Link

Elfahmi, Woerdenbag HJ, and Kayser 0 (2014). Jamu: Indonesian traditional herbal medicine towards rational phytopharmacological use. Journal of Herbal Medicine, 4(2): 51-73. Doi: https://doi.org/10.1016/i.hermed.2014.01.002 I Article Link

Ervina D, Ekowati T, Prasetyo E, Setiadi A, and Sumardjono D (2019). Analysis of Factors Influencing Business Income Dairy Farming Farmers Group of Rejeki Lumintu in Sumurrejo Village, Gunungpati District, Semarang. Journal of Social Economics of Agriculture, 13(2): 187-200. Doi: https://doi.org/10.24843/SOCA.2019.v13.i02.p04 | Article link

Galli GM, Gerbet RR, Griss LG, Fortuoso BF, Petrolli TG, Boiago MM, Souza CF et al. (2020). Combination of herbal components (curcumin carvacrol, thymol, cinnamaldehyde) in broiler chicken feed: Impacts on response parameters, performance, fatty acid profiles, meat quality and control of coccidia and bacteria. Microbial Pathogenesis, 139:103916. Doi: https://doi.org/10.1016/j.micpath.2019.103916 PMID: 31812772 | Article Link

Gaucher ML, Quessy S, Letellier A, Arsenault J, and Boulianne M (2015). Impact of a drug-free program on broiler chicken growth performances, gut health, Clostridium perfringens and Campylobacter jejuni occurrences at the farm level. Poultry Science, 94(8): 1791-1801. Doi: https://doi.org/10.3382/ps/pev142 | Article Link :

Hou Y, Wu Z, Dai Z, Wang G, and Wu G (2017). Protein hydrolysates in animal nutrition: Industrial production, bioactive peptides, and functional significance. Journal of Animal Science and Biotechnology, 8(1): 1-13. Doi: https://doi.org/10.1186/s40104-017-0153-9 I Article Link

Jamili MA, Hidayat MN, and Hifizah A (2014). Inhibition Test of Herbal Potion on the Growth of Staphylococcus Aureus and Salmonella Thypi. Journal of Animal Science and Industry, 1(3):227-239. Article Link

Jonker A, and Yu P (2017). The occurrence, biosynthesis, and molecular structure of proanthocyanidins and their effects on legume forage protein precipitation, digestion and absorption in the ruminant digestive tract. International Journal of Molecular Sciences, 18(5): 1105. Doi: https://doi.org/10.3390/ijms18051105 I Article Link

Kaewtapee C, Burbach K, Tomforde G, Hartinger T, Camarinha-Silva A, Heinritz S, Seifert J, Wiltafsky M, Mosenthin R, and RosenfelderKuon $P$ (2017). Effect of Bacillus subtilis and Bacillus licheniformis supplementation in diets with low- and high-protein content on ileal crude protein and amino acid digestibility and intestinal microbiota composition of growing pigs. Journal of Animal Science and Biotechnology, 8: 37. Doi: https://doi.org/10.1186/s40104-017-0168-2 I Article Link

Ketnawa S, and Ogawa Y (2019). Evaluation of protein digestibility of fermented soybeans and changes in biochemical characteristics of digested fractions. Journal of Functional Foods, 52: 640-647. Doi: https://doi.org/10.1016/j.jff.2018.11.046 | Article link

Kusbiyantari A, Kardaya D, Sudrajat D. (2017). The efficacy of papaya leaf extract inclusion in drinking water as an improving of layer quail production. Jurnal Peternakan Nusantara. 3(1): 31-40. Doi: http://dx.doi.org/10.30997/ipnu.v3i1.855 I Article Link

Liao SF, and Nyachoti M (2017). Using probiotics to improve swine gut health and nutrient utilization. Animal Nutrition, 3(4): 331-343. Doi: https://doi.org/10.1016/j.aninu.2017.06.007 I Article Link :

Li L, Liu Y, Zou X, He J, Xu X, Zhou G, and Li C (2017). In vitro protein digestibility of pork products is affected by the method of processing. Food Research International, 92: 88-94. Doi: https://doi.org/10.1016/j.foodres.2016.12.024 | Article Link

Milanovic S (2018). Literature review on the influence of milling and pelleting on nutritional quality, physical characteristics, and production cost of pelleted poultry feed. Title: Literature review on the influence of milling and pelleting on nutritional quality, physical. Master's Thesis, Norwegian University of Life Sciences, Norway. Article link

Mosihuzzaman M (2012). Herbal medicine in healthcare-an overview. Natural Product Communications, 7(6): 807-812. Doi: https://doi.org/10.1177/1934578x1200700628 I Article Link

Olijhoek DW, LøvendahI P, Lassen J, Hellwing ALF, Höglund JK, Weisbjerg MR, Noel SJ, McLean F, Højberg O, and Lund P (2018). Methane production, rumen fermentation, and diet digestibility of Holstein and Jersey dairy cows being divergent in residual feed intake and fed at 2 forage-to-concentrate ratios. Journal of Dairy Science, 101(11): 9926-9940. Doi: https://doi.org/10.3168/jds.2017-14278 I Article Link

Rabinowitch LC (2002). Allium Crop Sciences : Recent Advances. Wallingford, CABI Publishing, UK, p.101-117. Article Link

Shah AM, Wang Z, and Ma J (2020). Glutamine metabolism and its role in immunity, a comprehensive review. Animals, 10(2):1-13. Doi: https://doi.org/10.3390/ani10020326 I Article Link

Variani V, Pagala MA, and Hafid H (2017). Study of Physical Quality of Broiler Chicken at Various Cut Weights and Different Commercia Feed. Journal of Tropical Animal Science and Technology, 4(2): 40-48. Doi: https://doi.org/10.33772/jitro.v4i2.3785 | Article Link

Wilkie DS, Starkey M, Abernethy K, Effa EN, Telfer P, Godoy R (2005). Role of Prices and Wealth in Consumer Demand for Bushmeat in Gabon, Central Africa. Conservation Biology, 19(1): 268-274. Doi: https://doi.org/10.1111/j.1523-1739.2005.00372.x I Article Link

Zaghari M, Sarani P, and Hajati H (2020). Comparison of two probiotic preparations on growth performance, intestinal microbiota, nutrient digestibility and cytokine gene expression in broiler chickens. Journal of Applied Animal Research, 48(1): 166-175. Doi: https://doi.org/10.1080/09712119.2020.1754218 I Article Link

Zhu $F(2020)$. A review on the application of herbal medicines in the disease control of aquatic animals. Aquaculture, 526(January): 735422. Doi: https://doi.org/10.1016/j.aquaculture.2020.735422 | Article link 